Short Review

\title{
Probing of Protein Kinase Activity by Electrochemistry
}

\section{Lin Liu ${ }^{*}$ and Xin Wang}

Henan Province of Key Laboratory of New Optoelectronic Functional Materials, College of Chemistry and Chemical Engineering, Anyang Normal University, Anyang, Henan 455000, People's Republic of China

*E-mail: liulin82414@ aliyun.com

doi: $10.20964 / 2016.10 .59$

Received: 2 August 2016 / Accepted: 28 August 2016 / Published: 6 September 2016

Protein kinase can catalyze the transfer of a phosphoryl group from adenosine triphosphate (ATP) to protein/peptide substrate at the serine, tyrosine or threonine residues. The phosphorylation can induce the surface charge change of substrate peptides-modified electrode; the reaction could be measured by the change of the electrochemical impedance or the tyrosine oxidation current. The phosphate groups can be selectively recognized by anti-phosphorylated peptide antibody and metal ions, metal complexes as well as metal nanoparticles through the coordination or electrostatic interaction, which facilitated the design of various electrochemical kinase biosensors. Furthermore, the $\gamma$-phosphatemodified ATP analogues (e.g. biotinylated, sulfated and ferrocene-labeled ATP) have been used as the co-substrates of phosphorylation to monitor protein kinase activity. All of these electrochemical strategies for kinase assays were summarized in the present work.

Keywords: kinase; phosphorylation; electrochemistry; adenosine triphosphate; self-assembled monolayers

\section{$\underline{\text { FULL TEXT }}$}

(C) 2016 The Authors. Published by ESG (www.electrochemsci.org). This article is an open access article distributed under the terms and conditions of the Creative Commons Attribution license (http://creativecommons.org/licenses/by/4.0/). 